\title{
Microsatellite analysis of pacu broodstocks used in the stocking program of Paranapanema River, Brazil
}

Jayme Aparecido Povh ${ }^{1 *}$; Ricardo Pereira Ribeiro ${ }^{2}$; Nelson Mauricio Lopera-Barrero'; Carolina Bespalhok Jacometo ${ }^{2}$; Lauro Vargas²; Patrícia Cristina Gomes²; Taís da Silva Lopes ${ }^{3}$

${ }^{1}$ UFMT/Inst. de Ciências Agrárias e Tecnológicas, Rod. MT 270, km 06 - 78735-901 - Rondonópolis, MT Brasil.

${ }^{2}$ UEM/Centro de Ciências Agrárias - Núcleo de Pesquisa PeixeGen, Av. Colombo, 5790 - 87020-900 - Maringá, PR - Brasil.

${ }^{3}$ UNESP/CAUNESP - Via de Acesso Prof. Paulo Donato Castellane, s/n - 14884-900 Jaboticabal, SP - Brasil.

*Corresponding author <jayme.peixegen@gmail.com>

ABSTRACT: Monitoring the genetic diversity has fundamental importance for fish stocking programs. This experiment aims to evaluate the genetic diversity in two hatchery stations (A and B) with pacu Piaractus mesopotamicus (Holmberg, 1887) in Andirá, state of Paraná, Brazil used in stocking programs of Paranapanema River. Six microsatellite loci were amplified using DNA extracted from 60 fin-clipping samples. The broodstock B had the average number of alleles and the mean heterozygosity (alleles: 3.7 and $H_{\mathrm{O}}$ : 0.628 ) higher than the broodstock A (alleles: 3.5 and $H_{\mathrm{O}}$ : 0.600). Alleles with low frequency levels were observed in the both broodstocks. The positive coefficients of endogamy in the locus Pme2 (broodstock A: $F_{\text {IS }}=0.30$ and broodstock B: $F_{\text {IS }}=0.20$ ), Pme5 (broodstock B: $F_{\text {IS }}=0.15$ ), Pme14 (broodstock A: $F_{\text {IS }}=0.07$ ) and Pme28 (broodstock A: $F_{\text {IS }}=0.24$ and broodstock B: $F_{\text {IS }}=0.20$ ) indicated deficiency of heterozygotes. Presence of null allele in the locus Pme 2 was detected. The negative estimates in loci Pme4 (broodstock A: $F_{\text {IS }}=-0.43$ and broodstock B: $F_{\text {IS }}=-0.37$ ), Pme5 (broodstock A: $F_{\mathrm{IS}}=-0.11$ ), Pme14 (broodstock B: $F_{\mathrm{IS}}=-0.15$ ) and Pme32 (broodstock A: $F_{\mathrm{IS}}=-0.93$ and broodstock B: $\left.F_{\mathrm{IS}}=-0.60\right)$ were indicating the excess of heterozygotes. Evidence of linkage disequilibrium and lower allelic richness was found only in the broodstock A. Nei's gene diversity was high in both broodstocks. The genetic distance $(0.085)$ and identity $(0.918)$ showed similarity between broodstocks, which reflects a possible common origin. $6.05 \%$ of the total genetic variance was due to differences among broodstocks. Recent bottleneck effect in two broodstocks was observed. The results indicated a higher genetic diversity in the two broodstocks and they presented low genetic difference. This was caused by the reproductive management in both hatchery stations, reduction of population size and genetic exchange between the hatchery stations.

Key words: Piaractus mesopotamicus, genetic variability, hatchery stations, molecular markers

\section{Análise microssatélite de estoques de reprodutores de pacu utilizados no programa de repovoamento do rio Paranapanema}

RESUMO: O monitoramento da diversidade genética é fundamental em um programa de repovoamento. Avaliouse a diversidade genética de pacu Piaractus mesopotamicus (Holmberg, 1887) em duas estações de piscicultura em Andirá - Paraná, Brasil, utilizadas no programa de repovoamento do Rio Paranapanema. Foram amplificados seis loci microssatélite para avaliar 60 amostras de nadadeira. O estoque de reprodutores $\mathrm{B}$ apresentou maior número de alelos e heterozigose (alelos: 22 e $H_{\mathrm{o}}$ : 0,628) que o estoque de reprodutores A (alelos: 21 e $H_{\mathrm{o}}:$ 0,600). Alelos com baixos níveis de frequência foram observados nos dois estoques. Os coeficientes positivos de endogamia no locus Pme2 (estoque A: $F_{\text {IS }}=0,30$ e estoque B: $F_{\text {IS }}=0,20$ ), Pme5 (estoque B: $F_{\text {IS }}=0,15$ ), Pme14 (estoque A: $F_{\text {IS }}=0,07$ ) e Pme28 (estoque A: $F_{\text {IS }}=0,24$ e estoque B: $F_{\text {IS }}=0,20$ ), indicaram deficiência de heterozigotos. Foi detectada a presença de um alelo nulo no lócus Pme2. As estimativas negativas nos loci Pme4 (estoque A: $F_{\text {IS }}=-0,43$ e estoque B: $F_{\text {IS }}=-0,37$ ), Pme5 (estoque A: $F_{\text {IS }}=-0,11$ ), Pme14 (estoque B: $F_{\text {IS }}=-0,15$ ) e Pme32 (estoque A: $F_{\text {IS }}=-0,93$ e estoque B: $\left.F_{\text {IS }}=-0,60\right)$ foram indicativas de excesso de heterozigotos. Foi evidenciado desequilíbrio de ligação e riqueza alélica baixa só no estoque A. A diversidade genética de Nei foi alta nos dois estoques. A distância $(0,085)$ e identidade $(0,918)$ genética mostraram similaridade entre os estoques, o qual reflete uma possível origem comum. $6,05 \%$ da variância genética total foi devida a diferenças entre os estoques. Foi observado um recente efeito gargalo nos dois estoques. Os resultados indicaram uma alta diversidade genética nos estoques de reprodutores e baixa diferenciação genética entre eles, o que foi causado pelo manejo reprodutivo das pisciculturas, redução do tamanho populacional e intercâmbio genético entre as pisciculturas.

Palavras-chave: Piaractus mesopotamicus, variabilidade genética, estação de piscicultura, marcadores moleculares

Introduction

In the Alto Paraná Basin, Paraná state Brazil, the
Paranapanema is the foremost tributary of the Paraná River. In this river, the ichthyofauna comprises about 155 species distributed in the different orders (Britto et al., 2003). The 
pacu is classified in the order Characiformes, family Characidae, sub-family Serrasalminae, and the species is the Piaractus mesopotamicus (Holmberg, 1887) which is endemic in the Neotropical region, and widely distributed along the Paraná, Paraguay and Uruguay basins (Urbinati and Gonçalves, 2005). The pacu, which is now endangered along the Paranapanema river (Bressan et al., 2009), has been important either in the wild or in the fish farming due to its important economic contribution to the national fish market (IBAMA, 2007).

In Brazil, endangering or even the extinction of many freshwater species has been caused by water pollution, soil erosion, and over fishing (Agostinho et al., 2003; Hatanaka et al., 2006). Moreover, the Paranapanema river is obstructed by ten power plants (Leuzzi et al., 2004) which have been affecting the migratory path, and modifying the life cycle of several aquatic organisms along several ecosystems (Agostinho et al., 2003). Currently, many hatchery stations are releasing juveniles for enhancing the natural populations, and reducing the adverse effects in the fish stocks of many rivers. In the State of Paraná, more than 8.5 million of juveniles were released into the Paranapanema, where the aim is to release 20 million of juveniles (SEAB, 2006).

Although these governmental programs have been releasing the juveniles for more than three decades (Agostinho et al., 2003), the broodstocks still have to be evaluated for the presence of genetic diversity, since the similarity reduces the effectiveness of the program. Therefore, monitoring the genetic diversity is of fundamental importance to the longterm success of any stocking program (Povh et al., 2008; Lopera Barrero, 2009), and the microsatellite marker is the foremost method for achieving these purposes (Calcagnotto and DeSalle, 2009; Liu et al., 2005; Ortega-Villaizán Romo et al., 2006).

In the present study, we estimated the genetic diversity of pacu reared in two hatchery stations (captive broodstock A and captive broodstock B) at Andirá, Paraná, Brazil.

\section{Material and Methods}

In May 2007, we collected 30 fin-clipping samples from each captive broodstock of pacu reared in two hatchery stations (A and B) in Andirá (23 $03^{\prime} \mathrm{S}$ and $50^{\circ} 13^{\prime} \mathrm{W}$ ), Paraná, Brazil. These hatchery stations are important because they have been enhancing the fish stocking program in the Paranapanema river. These 5-year-old captive broodstocks (F1), without the introduction of new individuals, had their parents collected in the Paraná River, but there was no record of the reproductive management adopted before the establishment of both broodstocks. Currently, the extrusion reproductive system (Zaniboni-Filho and Nuñer, 2004) is the most used in the two fish farms aiming to obtain offspring for stocking programs.

DNA was isolated from fin-clipping with $0.5 \mathrm{~cm}^{-2}$, and the extraction was based on the methods described by Lopera Barrero et al. (2008). Samples were treated with $550 \mu \mathrm{L}$ lise buffer $(50 \mathrm{mM}$ Tris- $\mathrm{HCl}, 50 \mathrm{mM}$ EDTA, $100 \mathrm{mM} \mathrm{NaCl}$, and $1 \% \mathrm{SDS}), 7 \mu \mathrm{L}^{-1}$ proteinase $\mathrm{K}\left(200 \mu \mathrm{g} \mathrm{mL} \mathrm{m}^{-1}\right)$ per sample, and incubated overnight at $50^{\circ} \mathrm{C}$. Then, $600 \mu \mathrm{L}^{-1} 5 \mathrm{M} \mathrm{NaCl}$ were added to each sample before being centrifuged for $10 \mathrm{~min}$ at $12,000 \mathrm{rpm}$. The aqueous layer was removed carefully to new microtubes where the DNA was precipitated with $700 \mu \mathrm{L}$ of freezing ethanol and incubated later at $-20^{\circ} \mathrm{C}$ for $2 \mathrm{~h}$. The DNA samples were centrifuged again, washed with $700 \mu \mathrm{L}$ $70 \%$ ethanol, re-suspended in TE buffer $(10 \mathrm{mM}$ Tris and 1 $\mathrm{mM}$ EDTA), and treated with with $6 \mu \mathrm{L}^{-1}$ RNAse $(30 \mu \mathrm{g}$ $\left.\mathrm{mL}^{-1}\right)$ at $38^{\circ} \mathrm{C}$ for $40 \mathrm{~min}$. The DNA was quantified by comparing concentrations of DNA fago $\lambda$ in $1 \%$ agarose gel. The electrophoresis was carried out in TAE 1X (40 mM Tris-acetate and $1 \mathrm{mM}$ EDTA) buffer at $70 \mathrm{~V}$ for $1 \mathrm{~h}$, the profile was visualized under UV-radiation, and photographed with Kodak EDAS-290 (Kodak 1D Image analysis 3.5).

The DNA was amplified to $20 \mu \mathrm{L}^{-1}$ by using the buffer 1X Tris- $\mathrm{KCl}, 2.0 \mathrm{mM} \mathrm{MgCl}, 0.8 \mu \mathrm{M}$ from each primer (forward and reverse), $0.2 \mathrm{mM}$ dNTP, one unit of Platinum Taq DNA polymerase and $20 \mathrm{ng}^{-1}$ DNA. The following primers (Calcagnotto et al., 2001) were used: Pme2 (GenBank accession AF362445), Pme4 (AF362446), Pme5 (AF362447), Pme14 (AF362448), Pme28 (AF362451) and Pme32 (AF362452). The PCR reactions were performed with Eppendorf Mastercycler Gradient thermocycler under the following conditions: initial denaturation for $4 \mathrm{~min}$ at $94^{\circ} \mathrm{C}$, 30 cycles of $30 \mathrm{~s}$, denaturation at $94^{\circ} \mathrm{C}, 30 \mathrm{~s}$ at a primer-specific annealing temperature (Table 1 ), and 1 min of extension at $72^{\circ} \mathrm{C}$ followed by final extension for $10 \mathrm{~min}$ at $72^{\circ} \mathrm{C}$.

The amplified samples were submitted to gel electrophoresis by using $10 \%$ polyacrylamide (acrylamide:bisacrylamide - 29:1), denaturant (6 M urea), and $1 \mathrm{X}$ TBE buffer (90 $\mathrm{mM}$ Tris-Borate and $2 \mathrm{mM}$ EDTA) by using $50 \mathrm{~mA}$ for $7 \mathrm{hrs}$. The alleles were detected by silver nitrate according to Bassan et al. (1991). In the present case, the gel was fixed by using $10 \%$ ethanol and $0.5 \%$ acetic acid for 20 minutes, coloured by $6 \mathrm{mM} \mathrm{Ag} \mathrm{NO}_{3}$ for 10 minutes, and fixed by $0.75 \mathrm{M}$ of $\mathrm{NaOH}$ and $0.22 \%$ of $40 \%$ formaldehyde. A Sony digital camera DSC-P93A was used to photograph the gels. The size of the alleles was calculated by using the Kodak EDAS-290 program, and the 10 bp and 50 bp DNA Ladders were used as the markers.

The number and frequency of alleles, the observed $\left(H_{\mathrm{O}}\right)$ and the expected $\left(H_{\mathrm{E}}\right)$ heterozygosity, and the HardyWeinberg equilibrium were calculated by using the GENEPOP 4.0.6 (Rousset, 2007). Tests for HardyWeinberg's equilibrium (EWH) at every locus was based on a test analogous to the Fisher's exact test for the Markovchain method (Markov chain length: 100,000; dememorizations: 10,000) which was run in the same statistical software. The significance of P-values was adjusted following Bonferroni sequential corrections for multiple simultaneous statistical tests (Rice, 1989), with an initial alpha value of $0.05 \mathrm{k}, \mathrm{k}$ being the number of tests. To test the possibility of null allele occurrence, which can be one of the causes of heterozygote deficiencies, we estimated the expected frequency of a presumed null allele using the MICROCHECKER 2.2.3 program (Van Oosterhout et al., 2004). This program was also used to test the effect Wahlund in the EWH deviation.

The reduction in the average proportion of heterozygosity genotypes within broodstocks $\left(F_{\text {IS }}\right)$ was calculated to ad- 
Table 1 - Characterization of loci investigated and frequency of alleles in Piaractus mesopotamicus broodstocks.

\begin{tabular}{|c|c|c|c|c|c|c|c|c|}
\hline Locus & Primer sequence (5'- 3') & Motif & $\mathrm{T}$ & S & A & $\begin{array}{c}\text { Broodstock } \\
\text { A } \\
\end{array}$ & A & $\begin{array}{c}\text { Broodstock } \\
\text { B } \\
\end{array}$ \\
\hline \multirow{5}{*}{ Pme2 } & F: TGGGTGCACAGCACAGTAAC & $(\mathrm{GT})_{18}$ & 60 & 195 & 5 & 0.117 & 5 & 0.200 \\
\hline & R: TTTGCATTTCTGGTGCAAAG & & & 205 & & 0.267 & & 0.117 \\
\hline & & & & 207 & & 0.450 & & 0.250 \\
\hline & & & & 210 & & 0.117 & & 0.283 \\
\hline & & & & 213 & & 0.050 & & 0.150 \\
\hline \multirow{4}{*}{ Pme4 } & F: CATGCTGCTGCAGATTAGAC & $(\mathrm{GT})_{14}$ & 60 & 191 & 4 & 0.036 & 4 & 0.196 \\
\hline & R: CGCTTGCAATTTAACGCAGT & & & 200 & & 0.518 & & 0.446 \\
\hline & & & & 202 & & 0.304 & & 0.196 \\
\hline & & & & 203 & & 0.143 & & 0.161 \\
\hline \multirow{5}{*}{ Pme5 } & F: CAGAGCATCTGGAGGGACAT & $\begin{array}{c}(\mathrm{GA})_{10} \text { gggagctggta } \\
(\mathrm{GT})_{10} \mathrm{C}(\mathrm{GT})_{12}\end{array}$ & 60 & 182 & 4 & 0.317 & 5 & 0.357 \\
\hline & R: TCTGAGACACTGATATCTAAACACACA & & & 186 & & 0.083 & & 0.107 \\
\hline & & & & 187 & & 0.250 & & 0.054 \\
\hline & & & & 200 & & 0.350 & & 0.268 \\
\hline & & & & 203 & & 0 & & 0.214 \\
\hline \multirow{3}{*}{ Pme14 } & F:ACCGTTATGCCCTACCCTTC & $(\mathrm{CTG})_{7}$ & 62 & 195 & 3 & 0.183 & 3 & 0.250 \\
\hline & R: GCGTTCTAGACAGAACTCATGG & & & 200 & & 0.783 & & 0.596 \\
\hline & & & & 203 & & 0.033 & & 0.154 \\
\hline \multirow{2}{*}{ Pme28 } & F: CCCAGAAGAGTGGAAGCTGT & $(\mathrm{GT})_{15}$ & 60 & 209 & 2 & 0.138 & 2 & 0.362 \\
\hline & R: TGGTGGGAATTGACAAGAAA & & & 214 & & 0.845 & & 0.638 \\
\hline \multirow{3}{*}{ Pme32 } & F: GCGAGAAATCTGCCTGTGAC & $(\mathrm{CTG})_{7}$ & 66 & 242 & 3 & 0.482 & 3 & 0.310 \\
\hline & R: AGGAGGGCATCATGGAGAA & & & 245 & & 0.500 & & 0.500 \\
\hline & & & & 247 & & 0.018 & & 0.190 \\
\hline
\end{tabular}

A: Numbers of alleles; T: Annealing temperature $\left({ }^{\circ} \mathrm{C}\right)$; S: Size of alleles (bp).

dress the EWH deviation. $F_{\text {IS }}$ from each broodstock for each locus was calculated using FSTAT 2.9.3.2 (Goudet, 2002). The distortion from independent segregation of genotypes (linkage disequilibrium) was tested using the exact test (Markov chain: dememorization: 1000; batches: 100; iterations per batch: 1000) (Guo and Thompson, 1992) facilitated also by GENEPOP 4.0.6. To quantify hierarchical genetic variation between broodstocks, the analyses of molecular variance (AMOVA) was performed following Excoffier et al. (1992) using the program ARLEQUIN version 2.0 (Excoffier et al., 2005). The genetic distance and identity and Nei's gene diversity were calculated by using the POPGENE 1.31 (Yeh et al., 1999). A recent reduction of effective population size (bottleneck) was tested in the broodstocks using the BOTTLENECK version 1.2.02 program (Cornuet and Luikart, 1996). The Duncan test was used to determine differences between means.

\section{Results and Discussion}

All six primer pairs used in this study were polymorphic and amplified consistent and reproducible microsatellite alleles with the allele size ranging from 182 (Pme5) to $247 \mathrm{bp}$ (Pme32). The average number of alleles per locus per broodstock ranged from $3.5( \pm 1.05)$ in A to 3.7 ( \pm 1.21$)$ in $\mathrm{B}$
(Table 1). Alleles with low frequency levels (lower than 0.1) were observed in the broodstock A (Pme2: 213 bp; Pme4: 191 bp; Pme5: 186 bp; Pme14: 203 bp and Pme32: 247 bp) and the broodstock B (Pme5: 187 bp). The allele with 203 bp in the locus Pme5 was not detected in the broodstock A (Table 1).

The broodstock A had the observed heterozigosity $\left(H_{\mathrm{O}}\right)$ in the loci Pme 5 and Pme32 higher than the broodstock B, which had higher number of heterozygotes in the loci Pme2, Pme4, Pme14 and Pme28. The average $H_{0}$ was slightly higher $(0.628 \pm 0.29)$ in the broodstock B than in the A $(0.600 \pm$ 0.18 ) (Duncan test, $p<0.05$ ) (Table 2). The difference between the broodstocks for both the observed and the mean heterozygosity was small $(p<0.05)$. However, the highest number of alleles under low frequency levels, and the absence of the 203 bp allele (locus Pme5) in the broodstock A may contribute to indicating low genetic diversity in this broodstock. Changes in the frequencies of alleles and the absence of alleles in commercial stocks may be due to genetic drift and inbreeding that creates differentiation processes, with according Cameron-Brown et al. (2005) are caused by low effective population size $\left(N_{\mathrm{e}}\right)$. Therefore, some alleles of the broodstock A can be eliminated in the next generations (Innes and Elliott, 2006).

The positive coefficients of endogamy in the locus Pme2 (broodstock A: $F_{\text {IS }}=0.30$ and broodstock B: $F_{\text {IS }}=0.20$ ), 
Table 2 - Observed $\left(H_{\mathrm{O}}\right)$ and expected $\left(H_{\mathrm{E}}\right)$ heterozygosities, coefficient of endogamy $\left(F_{\mathrm{IS}}\right)$, probability test for the HardyWeinberg equilibrium (PHW), Nei's gene diversity $(h s)$ and number of alleles by locus $\left(\mathrm{N}_{\mathrm{A}}\right)$ in loci investigated in broodstocks of Piaractus mesopotamicus.

\begin{tabular}{|c|c|c|c|c|c|c|c|c|c|c|c|c|}
\hline \multirow{2}{*}{ Locus } & \multicolumn{6}{|c|}{ Broodstock A } & \multicolumn{6}{|c|}{ Broodstock B } \\
\hline & $H_{O}$ & $H_{E}$ & $F_{I S}$ & EWH & hs & $N_{A}$ & $H_{O}$ & $H_{E}$ & $F_{I S}$ & EWH & bs & $N_{A}$ \\
\hline Pme2 & $0.50^{\mathrm{NS}}$ & 0.71 & 0.30 & $0.004^{* *}$ & 0.70 & 5.0 & $0.63^{\mathrm{NS}}$ & 0.79 & 0.20 & $0.003^{* *}$ & 0.78 & 5.0 \\
\hline Pme4 & $0.83^{* *}$ & 0.59 & -0.43 & $0.011^{* *}$ & 0.62 & 4.0 & $0.90 * *$ & 0.66 & -0.37 & $0.000^{* *}$ & 0.70 & 4.0 \\
\hline Pme5 & $0.80^{* *}$ & 0.72 & -0.11 & $0.060^{\mathrm{NS}}$ & 0.71 & 4.0 & $0.60^{\mathrm{NS}}$ & 0.70 & 0.15 & $0.118^{\mathrm{NS}}$ & 0.74 & 5.0 \\
\hline Pme14 & $0.33^{\mathrm{NS}}$ & 0.36 & 0.07 & $0.515^{\mathrm{NS}}$ & 0.35 & 3.0 & $0.57^{* *}$ & 0.49 & -0.15 & $0.144^{\mathrm{NS}}$ & 0.56 & 3.0 \\
\hline Pme28 & $0.20^{\mathrm{NS}}$ & 0.26 & 0.24 & $0.053^{\mathrm{NS}}$ & 0.24 & 2.0 & $0.37^{\mathrm{NS}}$ & 0.45 & 0.20 & $0.416^{\mathrm{NS}}$ & 0.46 & 2.0 \\
\hline Pme32 & $0.93^{* *}$ & 0.49 & -0.93 & $0.000 * *$ & 0.52 & 3.0 & $0.70 * *$ & 0.44 & -0.60 & $0.000 * *$ & 0.62 & 3.0 \\
\hline Mean & $0.60 \mathrm{~b}$ & $0.52 \mathrm{~b}$ & -0.16 & - & $0.52 \mathrm{~b}$ & 3.5 & $0.63 \mathrm{a}$ & $0.59 \mathrm{a}$ & -0.09 & - & $0.64 \mathrm{a}$ & 3.7 \\
\hline
\end{tabular}

$H_{\mathrm{O}}$ and EWH: Ns- Not significant and ${ }^{* *}$ - Highly significant $(p<0.008$ for six events) after Bonferroni adjustment (nominal $\alpha=0.05)$.

Pme5 (broodstock B: $\left.F_{\text {IS }}=0.15\right)$, Pme14 (broodstock A: $F_{\text {IS }}$ $=0.07$ ) and Pme28 (broodstock A: $F_{\text {IS }}=0.24$ and broodstock B: $\left.F_{\text {IS }}=0.20\right)$ indicating deficiency of heterozygotes. The MICRO-CHECKER software analysis only detected the presence of null allele in this locus. In contrast, the negative estimates in loci Pme4 (broodstock A: $F_{\text {IS }}=-0.43$ and broodstock B: $F_{\text {IS }}=-0.37$ ), Pme5 (broodstock A: $F_{\text {IS }}=-0.11$ ), Pme14 (broodstock B: $F_{\text {IS }}=-0.15$ ) and Pme32 (broodstock A: $F_{\text {IS }}=-0.93$ and broodstock B: $\left.F_{\text {IS }}=-0.60\right)$ are indicating the excess of heterozygotes.

In both captive broodstocks, the deficiency of heterozygotes in the locus Pme2 may be not attributed to the inbreeding. Probably, the presence of null alleles indicated by MICRO-CHECKER analysis for this locus is contributing to reduce the heterozygosity levels. Unfortunately, the management decisions that were made to rear the present broodstocks are unknown. On the other hand, the excess of heterozygotes indicate that despite the presence of heterozygote deficiency in loci Pme2, Pme5, Pme14 e Pme28 the broodstock is not experiencing a process of inbreeding. A significant $(p>0.05)$ Wilcoxon test and the shift-mode of allele frequency distribution obtained by BOTTLENECK program, showed that a recent bottleneck had occurred in two broodstocks, suggesting that a severe reduction of population size occurred. Usually bottleneck is always accompanied by homozygote excess, which causes a reduction of genetic variability.

Endogamy, small effective number of contributing parents $\left(N_{\mathrm{e}}\right)$, inappropriate selection of parents, founder effect and the misuse of the reproduction period are some constraints capable of inducing losses in the genetic variability (Povh et al., 2008). The breeding system used in mating (Lopera Barrero et al., 2010; Povh et al., 2010) and the use of sequential or simultaneous semen during artificial fertilization (Withler and Beacham, 1994) are also factors that may affect the genetic variability of progeny used in stocking programs. Reproductive management is of fundamental importance to preserve the genetic diversity of juveniles which will participate in the stocking programs. Nonetheless, the enhancing programs may have less survival of juveniles and, consequently, the populations in the wild will be permanently affected. The analysis of the genetic differences between the captive broodstocks and populations in the wild is also very important because every one has specific genes for local adaptability, and consequently the survival of juveniles will be affected (Sønstebø et al., 2007; Vasemägi et al., 2005).

Evidence of linkage disequilibrium $(p<0.05)$ was found only for Pme $4 \times$ Pme 32 locus pair in the broodstock A. This disequilibrium may be due to the number of samples collected. These results are similar to those obtained by Povh et al. (2010) where they observed different patterns of linkage disequilibrium in the parental and progeny fishes, without affecting the estimates of genetic diversity.

Both broodstocks had deviations in the Hardy-Weinberg equilibrium (EWH) for the loci Pme2, Pme4 and Pme32 after sequential Bonferroni correction $(p<0.008)$ (Table 2). Although HWE deviations may be due to the presence of null alleles, detected to Pme2 locus, the influence of the Wahlund effect can not be dismissed in these populations, which also showed excess of heterozygotes for other loci.

Nei's gene diversity (bs) was high in both broodstocks. It was found that this measurement of genetic variation ranged from $0.52( \pm 0.19)$ to $0.64( \pm 0.12)$ for the broodstocks A and B, respectively (Table 2). The Duncan test showed differences among broodstocks for $H_{\mathrm{O}}$ and $h s$ parameters $(p>0.05)$. The genetic distance $(0.085)$ and identity (0.918) showed similarity between broodstocks, which reflects a possible common origin. However, $6.05 \%$ of the total genetic variance was due to differences among broodstocks $(p<0.001)$ (Table 3$)$.

These results may be due to broodstocks expressing profiles of populations which could have been collected along the Basin of the Paraná River because this fact explains the differences in the heterozygosity and in the frequency of alleles. However, it is not possible to verify this hypothesis, since there is no information to report differences between natural populations of these rivers. Calcagnotto and DeSalle (2009) analyzed the genetic structure of $P$. mesopotamicus natural populations sampled inside and outside the Pantanal of Mato Grosso state, and did not observe a positive correlation between the genetic differentiation and the natural logarithm of geographical distances and when the sampling sites 
Table 3 - Analysis of molecular variance (AMOVA), genetic distance (GD) and identity (GI) in broodstocks of Piaractus mesopotamicus.

\begin{tabular}{|c|c|c|c|c|c|}
\hline Source of variation & Sum of squares & Variance components & Percentage of variation & GD & GI \\
\hline Among Broodstocks & 4,308 & 0.05704 & 6.05 & 0.085 & 0.918 \\
\hline Within Broodstocks & 104.533 & 0.88588 & 93.95 & & \\
\hline Total & 108.842 & 0.94292 & 100 & & \\
\hline
\end{tabular}

were compared there were also no genetic differentiation among them. Furthermore, Lervolino et al. (2010), using the D-loop control region of mtDNA sequence data to investigate genetic variability within and among populations of $P$. mesopotamicus in the different rivers in the Upper-Paraguay Basin, observed the absence of genetic differentiation, suggesting that the populations could be treated as a single genetic stock. Differences could also be caused by the reproductive management in both hatchery stations, which could be the cause of the low genetic diversity in the broodstock A. Therefore, special care with the reproductive management will be of fundamental importance for enhancing and then maintain the genetic diversity in the broodstock $\mathrm{A}$.

The excess of heterozygotes (loci Pme4, Pme5, Pme14 and Pme32) and the average $F_{\text {IS }}$ may be an indication of the genetic exchange between the hatchery stations, a fact that could explain the low genetic difference between both captive broodstocks (genetic distance: 0.085). This excess of heterozygotes may also indicate the breakdown of the Wahlund effect if they have been trained by fish collected from different locations of the Paraná River. However, the contribution of this effect in valued broodstocks should not be discarded. Calcagnotto et al. (2001) collected pacu in the Pantanal Basin, Mato Grosso, Brazil, and found different levels of the observed heterozygosity after analysing six microsatellite loci. Calcagnotto et al. (2001) found high levels of heterozygosity in the loci Pme2 (0.852), Pme14 (0.667), and Pme28 (0.643), but low levels in Pme4 (0.656) and Pme32 (0.200) in comparison to the responses from the present broodstocks (Table 1). However, in the locus Pme5 they found heterozigosity of 0.606 which was slightly higher than the present result from the broodstock B (0.600), but lower than found in the A (0.800). In all the loci, these authors detected a higher number of alleles ranging from 7 (Pme4) to 10 (Pme2 and Pme28), except in the locus Pme32 that had the same three alleles (Table 1). They had an average of 6.5 alleles per locus in comparison to 3.6 observed in the present study. These results may have also been caused by the fish origin, founder effects, and management decisions.

Currently, stocking programs have been the best alternative to the other methods for enhancing the native fish populations or the threatened species (Barroso et al., 2005; LoperaBarrero, 2009). However, the reduction in the genetic diversity can make the enhancement program inefficient, which means less survival of juveniles in the freshwater ecosystems and, therefore, irreversible effects on the native populations. Lopera-Barrero et al. (2009) to analyze P. mesopotamicus broodstocks used in stocking programs, recommended year- round evaluation of broodstocks used in this programs, of their offspring released in rivers, and of native populations to monitor the effectiveness of these programs and the possible effects on the ecosystem.

The genetic monitoring of broodstock and juveniles is important, and has to be included in the routine tests because this decision will make the reproductive management more efficient (Lopera-Barrero et al., 2009). Therefore, the broodstock used in stocking programs, as analyzed in this study, should begin with a large number of carefully selected individuals (Aho et al., 2006). The correct chioce of the reproducers to be used in the formation of broodstock and their genetic evaluation can offer important bases for formulating reproductive management strategies (Sønstebø et al., 2007). These strategies will permit safe exchange of broodstocks among fish farms stations to break up cycles of endogamy that are common in controlled environments (Moreira et al., 2007). Finally, monitoring the genetic diversity in conjunction with conservative decisions should be made in the present freshwater ecosystems. For this purpose, microsatellite markers have been used successfully in this paper and can be used to discriminate genotypes with breeding objectives (Muzzalupo et al., 2009), stocking programs (Povh et al., 2010) and conservation (Lopera Barrero, 2009).

\section{Acknowledgements}

To the Research Bureau in the State of Paraná for providing the funds for this study, the undergraduate students and the technicians for the important contributions to the success of this experiment.

\section{References}

Agostinho, A.A.; Gomes, L.C.; Suzuki, H.I.; Júlio Jr, H.F. 2003. Migratory fish of upper Paraná River basin, Brazil. p. 19-99. In: Carolsfeld, J.; Harvey, B.; Baer, A.; Ross, C., eds. Migratory fishes of South America: biology, fisheries, and conservation status. World Fisheries Trust, Victoria, BC, Canada.

Aho, T.; Rönn, J.; Piironen, J.; Björklund, M. 2006. Impacts of effective population size on genetic diversity in hatchery reared Brown trout (Salmo trutta L.) populations. Aquaculture 253: 244-248.

Barroso, R.M.; Hilsdorf, A.W.S.; Moreira, H.L.M.; Cabello, P.H.; TraubCseko, Y. 2005. Genetic diversity of wild and cultured populations of Brycon opalinus (Cuvier, 1819) (Characiforme, Characidae, Bryconiae) using microsatellites. Aquaculture 247: 51-65.

Bassan, B.J.; Caetano-Anollés, G.; Gresshoff, P.M. 1991. Fast and sensitive silver staining of DNA in polyacrylamide gels. Analytical Biochemistry 196: 80-83.

Brazilian Institute of Environment and Natural Resources [IBAMA]. Fishing Statistics 2007. Brazil: Major Regions and Federative Units. IBAMA, Brasília, DF, Brazil. (in portuguese). 
Bressan, P.M.; Kierulff, M.C.M.; Sugieda, A.M. 2009. Threatened Fauna in the São Paulo State: Vertebrates. Zoological Park Foundation of São Paulo/Department of the Environment, São Paulo, SP, Brazil. (in Portuguese).

Britto, S.G.C.; Sirol, R.N.; Vianna, N.C.; Jardim, M.S.; Santos, J.C.; Pelisari, E. 2003. Fish of Paranapanema river. Duke Energy Internacional/ Geração Paranapanema, São Paulo, SP, Brazil. (in Portuguese).

Calcagnotto, D.; Russello, M.; Desalle, R. 2001. Isolation and characterization of microsatellite loci in Piaractus mesopotamicus and their applicability in other Serrasalminae fish. Molecular Ecology Notes 1: 245-247.

Calcagnotto, D.; DeSalle, R. 2009. Population genetic structuring in pacu (Piaractus mesopotamicus) across the Paraná-Paraguay basin: evidence from microsatellites. Neotropical Ichthyology 7: 607616.

Cameron-Brown, R.; Woolliams, J.A.; McAndrew, B.J. 2005. Factors influencing effective population size in commercial populations of gilthead seabream, Sparus aurata. Aquaculture 247: 219-225.

Cornuet, J.M. ; Luikart, G. 1996. Description and power analysis of two tests for detecting recent population bottlenecks from allele frequency data. Genetics 144: 2001-2014.

Excoffier, L.; Laval, G.; Schneider, S. 2005. Arlequin ver. 3.0: an integrated software package for population genetics data analysis. Evolutionary Bioinformatics Online 1: 47-50.

Excoffier, L.; Smouse, P.E.; Quattro, J.M. 1992. Analysis of molecular variance inferred from metric distances among DNA haplotypes: application to human mitochondrial DNA restriction data. Genetics 131: 479-491.

Goudet, J. 2002. FSTAT, a program to estimate and test gene diversities and fixation indices (version 2.9.3.2). Available at http// www.unil.ch/izea/softwares/fstat.html. [Accessed Jul. 10, 2010].

Guo, S.; Thompson. E. 1992. Performing the exact test of HardyWeinberg proportion for multiple alleles. Biometrics 48: 361-372.

Hatanaka, T.; Henrique-Silva, F.; Galetti Jr, P.M. 2006. Population substructuring in a migratory freshwater fish Prochilodus argenteus (Characiformes, Prochilodontidae) from the São Francisco River. Genetica 126: 513-517.

Innes, B.H.; Elliott, N.G. 2006. Genetic diversity in a Tasmanian hatchery population of Atlantic salmon (Salmo salar L.) compared with its Canadian progenitor population. Aquaculture Research 37: 563569.

Lervolino, F.; Resende, E.K.; Hilsdorf, A.W.S. 2010. The lack of genetic differentiation of pacu (Piaractus mesopotamicus) populations in the Upper-Paraguay Basin revealed by the mitochondrial DNA Dloop region: implications for fishery management. Fisheries Research 101: 27-31.

Leuzzi, M.S.P.; Almeida, F.S.; Orsi, M.L.; Sodré, M.L.K. 2004. Analysis by RAPD of the genetic structure of Astyanax altiparanae (Pisces, Characiformes) in reservoirs of the River Paranapanema. Genetics and Molecular Biology 27: 355-362.

Liu, Y.; Chen, S.; Li, B. 2005. Assessing the genetic structure of three Japanese flounder (Paralichthys olivaceus) stocks by microsatellite markers. Aquaculture 243: 103-111.

Lopera-Barrero, N.M.; Povh, J.A.; Ribeiro, R.P.; Gomes, P.C.; Jacometo, C.B.; Lopes, T.S. 2008. Comparison of DNA extraction protocols of fish fin and larvae samples: modified salt $(\mathrm{NaCl})$ extraction. Ciencia e Investigación Agraria 35: 65-74.

Lopera Barrero, N.M. 2009. Conservation of Brycon orbignyanus natural populations and stocks for their reproductive, genetic, environmental sustainability: a model for species threatened with extinction. Ciencia e Investigación Agraria 36: 191-208.

Lopera Barrero, N.M.; Ribeiro, R.P.; Povh, J.A.; Vargas, L.; Jacometo, C.B.; Gomes, P.C. 2009. Genetic diversity in Piaractus mesopotamicus stocks used in stock enhancement programs and implications for conservation. Agrociencia 43: 249-256.

Lopera Barrero, N.M.; Vargas, L.; Sirol, R.N.; Ribeiro, R.P.; Povh, J.A.; Streit Jr, D.P.; Gomes, P.C. 2010. Genetic diversity and reproductive contribution of Brycon orbignyanus offspring in the semi-natural reproductive system using microsatellites markers. Agrociencia 44: $171-181$
Moreira, A.A.; Hilsdorf, A.W.S.; Silva, J.V.; Souza, V.R. 2007. Genetic variability of two Nile Tilapia strains by microsatellites markers. Pesquisa Agropecuaria Brasileira 42: 521-526. (in Portuguese, with abstract in English).

Muzzalupo, I.; Stefanizzi, F.; Salimonti, A.; Falabella, R.; Perri, E. 2009. Microsatellite markers for identification of a group of Italian olive accessions. Scientia Agricola 66: 685-690.

Ortega-Villaizán Romo, M.M.; Aritaki, M.; Taniguchi, N. 2006. Pedigree analysis of recaptured fish in the stock enhancement program of spotted halibut Verasper variegatus. Fisheries Science 72: 48-52.

Povh, J.A.; Ribeiro, R.P.; Sirol, R.N.; Streit Júnior, D.P.; Lopera-Barrero, N.M.; Vargas, L.; Gomes, P.C.; Lopes, T.S. 2008. Genetic diversity of pacu from the Paranapanema River and from the broodstock of a stock enhancement program. Pesquisa Agropecuária Brasileira 43: 201-206. (in Portuguese, with abstract in English).

Povh, J.A.; Ribeiro, R.P.; Sirol, R.N.; Streit Jr, D.P.; Moreira, H.L.M.; Siewerdt, F.; Lopera Barrero, N.M.; Mangolin, C.A.; Vargas, L. 2010. Microsatellite analysis of the parental contribution of Piaractus mesopotamicus to the production of offspring in the semi-natural system of reproduction. Brazilian Archives of Biology and Technology 53: 389-396.

Rice, W.R. 1989. Analyzing table of statistical tests. Evolution 43: 223225.

Rousset, F. 2007. Genepop 2007: a complete re-implementation of the GENEPOP software for Windows and Linux. Molecular Ecology Research 8: 103-106.

Secretaria da Agricultura e do Abastecimento do Paraná [SEAB]. 2006. Fish stock enhancement program of Paraná river. Available at http://www.agenciadenoticias.pr.gov.br. [Accessed Jul 9, 2010]. (in Portuguese).

Sønstebø, J.H.; Borgstrøm, R.; Heun, M. 2007. Genetic structure of brown trout (Salmo trutta L.) from the Hardangervidda mountain plateau (Norway) analyzed by microsatellite DNA: a basis for conservation guidelines. Conservation Genetics 8: 33-44.

Urbinati, E.C.; Gonçalves, F.D. 2005. Pacu (Piaractus mesopotamicus). p. 225-255. In: Baldisserotto, B.; Gomes, L.C., eds. Native species for hatchery stations in Brazil. UFSC, Santa Maria, SC, Brazil. (in Portuguese).

Van Oosterhout, C.; Hutchinson, W.F.D.; Wills, P.M.; Shipley, P. 2004. MICRO-CHECKER: software for identifying and correcting genotyping errors in microsatellite data. Molecular Ecology Notes 4: $535-538$.

Vasemägi, A.; Cross, R.; Paaver, T.; Koljonen, M.L.; Nilsson, J. 2005. Extensive immigration from compensatory hatchery releases into wild Atlantic salmon population in the Baltic sea: spatio-temporal analysis over 18 years. Heredity 95: 76-83.

Withler, R.E.; Beacham, T.D. 1994. Genetic consequences of the simultaneous or sequential addition of semen from multiple males during hatchery spawning of chinook salmon (Oncorbynchus tshareytscha). Aquaculture 126: 11-23.

Yeh, F.C.; Boyle, T.Y.Z.; Xiyan, J.M. 1999. POPGENE Version 131: Microsoft Window-Based Freeware for Population Genetic Analysis. University of Alberta/Center for International Forestry Research, Alberta, AB, Canada.

Zaniboni-Filho, E.; Nuñer, A.P.O. 2004. Physiology of reproduction and artificial propagation of fish. p. 45-73. In: Cyrino, J.E.P.; Urbinati, E.C.; Fracalossi, D.M.; Castagnolli, N., eds. Special topics in tropical freshwater fish farming intensive. TecArt, São Paulo, SP, Brazil. (in Portuguese).

Received October 30, 2009

Accepted January 28, 2011 